\title{
Intraocular lens power calculation by measuring axial length with partial optical coherence and ultrasonic biometry
}

\author{
Cálculo da dioptria da lente intraocular medindo o comprimento axial através de \\ interferometria de coerência parcial ou biometria ultrassônica
}

Beatriz Machado Fontes ${ }^{1}$, Bruno Machado Fontes ${ }^{2,3}$, Elaine Castro ${ }^{3}$

\begin{abstract}
Purpose: To compare the achieved refractive outcomes of patients undergoing cataract surgery with intraocular lens (IOL) power calculation performed by conventional immersion ultrasound (US) or partial coherence interferometry (PCl).

Methods: Prospective, comparative case series. Patients undergoing cataract surgery were randomly divided in two groups with regard to the IOL power calculation method. Group 1 had calculations performed by PCI (IOL Master; Carl Zeiss Meditec), while US was used in Group 2 (Ultrascan; Alcon), using the Holladay 1 formula. Differences between target and achieved refractions were then compared.

Results: The study comprised 120 eyes from 79 patients. Biometry with PCl was used in 50 eyes of 33 patients, and US was used in 70 eyes of 46 patients. Mean age of patients in the PCl Group was $69.8 \pm 13.1$ years (range $11-85)$ and $70.0 \pm 9.3(45-86)$ in the US Group ( $P=0.7165)$. Mean axial length measured by $P C I$ was $23.22 \pm 1.00 \mathrm{~mm}$ (range $21.01-25.45)$ and that by US was $23.22 \pm 1.06 \mathrm{~mm}(20.05-25.78)(P=0.9110)$. Mean absolute error in the PCl group was $0.15 \pm 0.33 \mathrm{D}$ (range -0.65 - 0.9) and that in the US group was $0.26 \pm 0.48 \mathrm{D}(-1.05-1.76)$. All eyes in the $\mathrm{PCl}$ group and $94.3 \%$ of those in the US group were within $1.00 \mathrm{D}$ of the planned refraction.

Conclusion: Although both $\mathrm{PCl}$ and US yielded good prediction in IOL power calculation, the $\mathrm{PCl}$ group tended to show better accuracy and improved refractive outcome.
\end{abstract}

Keywords: Diagnostic techniques, ophthalmological; Preoperative care; Cataract extraction; Lens implantation, intraocular; Refractive errors

\section{RESUMO}

Objetivo: Comparar os resultados refracionais obtidos em pacientes submetidos à cirurgia de catarata com cálculo da lente intraocular realizado por meio de biometria ultrassônica de imersão (US) ou por interferometria de coerência parcial (ICP).

Métodos: Série de casos comparativa, prospectiva. Os pacientes submetidos à cirurgia de catarata foram aleatoriamente divididos em dois grupos em relação ao método de cálculo do poder da lente intraocular (LIO) a ser implantada. O grupo 1 teve seu cálculo efetuado porICP(IOL Master:CarlZeiss Meditec), enquanto ogrupo 2 usou-se US (UItrascan: Alcon). A fórmula Holladay 1 foi utilizada nos dois grupos. As diferenças entre os resultados refracionais planejados e obtidos foram então comparadas.

Resultados: O estudo contou com 120 ol hos de 79 pacientes. Biometria por meio de ICP foi utilizada em 50 olhos de 33 pacientes e com US em 70 olhos de 46 pacientes. A idade média dos pacientes no grupo 1 foi de 69,8 $\pm 13,1$ anos e de 70,0 \pm 9,3 anos no grupo $2(P=0,7165)$. O comprimento axial médio aferido pela ICP foi de $23,22 \pm 1,00 \mathrm{~mm}$ (variando de 21,01 a 25,45 mm) e no grupo US foi de 23,22 $\pm 1,06 \mathrm{~mm}$ (variando de $20,05$ a 25,78 mm) ( $P=0,9110)$. O erro absoluto médio (diferença entre o planejado e 0 obtido) no grupo 1 foi de 0,15 0,33 D (variando de -0,65 a 0,9 D) e no grupo 2 de $0,26 \pm 0,48 \mathrm{D}$ (variando de $-1,05$ a 1,76 D). Todos os ol hos do grupo 1 e $94,3 \%$ dos olhos do grupo 2 obtiveram resultados refracionais de até 1,00 D de diferença do resultado refracional inicialmente planejado.

Conclusão: Os dois métodosestudados mostraram boa previsibilidaderefracionalquando utilizados para o cálculo do poder da LIO. No entanto, o grupo que utilizou ICP mostrou uma tendência a melhor acurácia, com menos dispersão de resultados.

Descritores: Técnicas de diagnóstico oftalmológico; Cuidados pré-operatórios; Extração de catarata; Implante de lente intraocular; Erros de refração

\section{INTRODUCTION}

Innovative techniques and advanced technology have greatly improved cataract surgery over the past few years. Modern techniques utilize small-incision phacoemulsification and foldable lens implantation ${ }^{(1)}$. Premium accommodative, toric, aspheric, and multifocal intraocular lenses (IOLs) are now widely available. There is an increased quest for accuracy, and patients are now seeking better results.

As a result, accurate biometry and power precision of IOLs have gained greater importance. Several factors influence the refractive outcome. Keratometry measurements, axial length, IOL power formulas, and anterior chamber depth are all related to better accuracy and refractive success ${ }^{(2,3)}$. Axial length (AL) measurements are essential for determining the accuracy of the $\mathrm{IOL}$ calculation and are probably the element with the largest potential for error. Inaccurate measurements can limit the predictability of refractive outcomes. Methods are still evolving, but ultrasound (US) biometry and partial coherence interferometry $(\mathrm{PCI})$ are the most commonly used methods for determining the IOL power.

Traditionally, ALs have been measured using ultrasound biometry, a time consuming exam that requires skilled biometrists. Contact Ascan ultrasonography is a well established method for measuring AL but immersion A-scan technique is potentially more accurate, since it does not require indentation of the cornea. More recently, $\mathrm{PCl}$ has emerged as a new modality for biometry with the advantages of being fast, noninvasive and less dependent on technician expertise.
Submitted for publication: November 18, 2010

Accepted for publication: April 17, 2011

Study carried out at the Centro de Microcirurgia e Diagnóstico - Rio de Janeiro (RJ), Brazil.

${ }^{1}$ Physician, Centro de Microcirurgia e Diagnóstico, Rio de Janeiro (RJ), Brazil.

Physician, Ophthalmology Department, Federal University of São Paulo - UNIFESP - São Paulo (SP), Brazil.

${ }^{3}$ Physician, Oftalmoclínica Méier, Rio de Janeiro (RJ), Brazil.
Funding: No specific financial support was available for this study.

Disclosure of potential conflicts of interest: B.M.Fontes, None; B.M.Fontes, None; E.Castro, None. Correspondence address: Beatriz M. Fontes. Av. das Américas 2.300 B casa 27 - Rio de Janeiro - RJ 22640-101 - Brazil - E-mail: beatriz_fontes@yahoo.com.br 
In this study, we performed IOL power calculations by conventional immersion US biometry or $\mathrm{PCl}$ and compared the refractive outcomes in patients who presented for cataract surgery.

\section{METHODS}

We employed a prospective, randomized, comparative case series study design. Consecutive patients were randomly separated into two groups based on the method used to calculate the IOL power, creating comparable groups. In Group 1, 50 eyes from 33 patients underwent biometry with $\mathrm{PCl}(\mathrm{IOL}$ Master Carl Zeiss Meditec, Dublin, CA, USA) to calculate the IOL power. In Group 2, 70 eyes from 46 patients underwent immersion US (Ultrascan, Alcon, Fort Worth, TX, USA) for IOL power calculation. An experienced ophthalmologist performed the immersion US and $\mathrm{PCl}$ measurements in all cases. The Holladay 1 formula was also used to calculate the IOL power in all patients.

The same surgeon performed small-incision phacoemulsification with the standard phaco-chop technique and in-the-bag implantation using an Acrysoft IQ model (Alcon) IOL in all cases. The final manifest refraction was assessed by the same examiner at least 4 weeks after the procedure.

Since certain calculation formulas for intraocular lens may be more precise depending on the axial length of the eye and the Holladay 1 formula was used in the study, eyes with axial length $<20 \mathrm{~mm}$ or $>25.8 \mathrm{~mm}$ were excluded. Other exclusion criteria were corneal astigmatism $>2.5$ diopters (D), complications during surgery, and patients with poor visual prognosis (eg, macular scar, amblyopia).

The desired final refraction was determined prior to surgery, and the final refractive outcome was compared between the two groups. The differences between the programmed final refraction and the achieved final refractive outcome for the two methodologies were compared. Spherical equivalent in diopters was used for programmed final refraction, final refractive outcome and mean absolute error.

The Wilcoxon rank-sum test was used to compare numerical variables between the two groups, and the chi-square test was performed to compare frequencies of categorical variables within the same group. The level of significance was set at 0.05, and the S-Plus 8.0 program was used for the statistical analysis.

\section{RESULTS}

We enrolled 120 eyes from 79 patients undergoing cataract surgery. The mean age of patients was $69.8 \pm 13.1$ years (range, $11-85$ years) in the PCI Group and $70.0 \pm 9.3$ (range, $45-86$ years) in the US Group ( $\mathrm{P}=0.7165$ ). The mean $\mathrm{AL}$ measured by the $\mathrm{PCl}$ was 23.22 $\pm 1.00 \mathrm{~mm}$ (range, $21.01-25.45 \mathrm{~mm}$ ) and that measured by US was $23.22 \pm 1.06 \mathrm{~mm}$ (range, $20.05-25.78 \mathrm{~mm}$ ) ( $\mathrm{P}=0.9110)$ (Table 1).

Table 2 shows the mean preoperative planned refractive outcome, the mean final achieved refraction, and the difference between the two values (mean absolute error, MAE). The MAE was 0.15 $\pm 0.33 \mathrm{D}$ (upper and lower of -0.65 and 0.9 , respectively) in the $\mathrm{PCl}$ group and $0.26 \pm 0.48 \mathrm{D}$ (upper and lower of -1.05 and 1.76 , respectively) in the US group ( $P=0.0836$ ). Although there was no statistical difference in the MAE between the two groups, figure 1 suggests that the variability of these differences was higher for the US group than for the $\mathrm{PCl}$ group.

In the $\mathrm{PCl}$ group, 68\% of the eyes achieved a postoperative refraction that differed by $<0.25 \mathrm{D}$ from the predicted value, as compared with $45.7 \%$ of the eyes in the US group. All eyes in the $\mathrm{PCl}$ group were within $1.00 \mathrm{D}$ of the planned refraction, and $94.3 \%$ of the eyes in the US group met this criterion. The accuracies of the predictions are given in table 3 .

Table 1. Patients demographics and axial length measurements

\begin{tabular}{lcc}
\hline & $\begin{array}{c}\text { Group 1 } \\
\text { (interferometry) }\end{array}$ & $\begin{array}{c}\text { Group 2 } \\
\text { (ultrasound) }\end{array}$ \\
\hline $\begin{array}{l}\text { Gender } \\
\text { Female }\end{array}$ & $18(55 \%)$ & $30(65 \%)$ \\
$\quad$ Male & $15(45 \%)$ & $16(35 \%)$ \\
$\begin{array}{l}\text { Age } \\
\text { Mean } \pm \text { SD } \\
\text { (range in years-old) }\end{array}$ & $69.8 \pm 13.1$ & $70.0 \pm 9.3$ \\
AL & $(11-85)$ & $(45-86)$ \\
$\quad$ Mean \pm SD & $23.22 \pm 1.00$ & $23.22 \pm 1.06$ \\
(range in mm) & $(21.01-25.45)$ & $(20.05-25.78)$ \\
\hline
\end{tabular}

$\mathrm{AL}=$ axial length; $\mathrm{SD}=$ standard deviation

Table 2. Programmed and achieved refraction

\begin{tabular}{lccc}
\hline & $\begin{array}{c}\text { Group 1 } \\
\text { (interferometry) }\end{array}$ & $\begin{array}{c}\text { Group 2 } \\
\text { (ultrasound) }\end{array}$ & $\begin{array}{c}\text { P } \\
\text { value }\end{array}$ \\
\hline $\begin{array}{l}\text { Programmed refractive outcome } \\
\text { Mean } \pm \text { SD }\end{array}$ & $-0.47 \pm 0.43 \mathrm{D}$ & $-0.76 \pm 0.26 \mathrm{D}$ & $<0.0001$ \\
$\quad(-2.15-0.75)$ & $(-1.59--0.33)$ & 0.0313 \\
$\begin{array}{l}\text { Final achieved refraction } \\
\quad \text { Mean } \pm \text { SD }\end{array}$ & $-0.32 \pm 0.54 \mathrm{D}$ & $-0.50 \pm 0.50 \mathrm{D}$ & $(-1.75-1.00)$ \\
$\quad$ (range in diopters) & $(-2.00-1.00)$ & $0.26 \pm 0.48 \mathrm{D}$ & 0.0836 \\
$\begin{array}{l}\text { Mean absolute error } \\
\text { (programmed - achieved) } \\
\quad \begin{array}{l}\text { Mean } \pm \text { SD } \\
\text { (range in diopters) }\end{array}\end{array}$ & $0.15 \pm 0.33 \mathrm{D}$ & $(-1.05-1.76)$ & \\
\hline
\end{tabular}

$\mathrm{D}=$ diopter $\mathrm{SD}=$ standard deviation 
The values for the final and programmed refractions showed a weak ( $r=0.3)$, but significant $(P=0.0127)$, correlation in the US group (Figure $2 \mathrm{~A}$ ). This weak correlation is seen in the Bland-Altman graphic (Figure 2 B). The mean refraction is represented on the horizontal axis, and the difference between the final and programmed refractions is indicated on the vertical axis. The chart demonstrates that the final values were generally higher, more hyperopic, than the programmed values ( $\mathrm{P}<0.0001$; Figure $2 \mathrm{C}$ ).

In the $\mathrm{PCl}$ group, the final and programmed refractions were strongly $(r=0.73)$ and significantly correlated $(P<0.0001)$. Figure $3 \mathrm{~A}$ indicates a better match between the final and programmed refractions in the $\mathrm{PCl}$ group than that shown in the corresponding US figure. The differences had less variation in the $\mathrm{PCl}$ group (Figure $3 \mathrm{~B}$ ), and the programmed and final refractions were significantly different ( $\mathrm{P}=0.0041$; Figure 4).

\section{DISCUSSION}

Younger patients with less visual disability are now undergoing surgery with higher expectations and demands for an optimal final result. As a consequence, cataract surgery is no longer just for visual rehabilitation but has also become a form of refractive surgery in which the final refractive result can define visual outcome. With the emergence of the so-called "premium IOLs," it became clear that an IOL power calculation was essential for determining the success of cataract surgery. Small biometric errors can limit IOL performan- ce and cause patient dissatisfaction and frustration. An incorrect lens power calculation is the main cause for dissatisfaction and lens exchange in modern cataract surgery ${ }^{(1-3)}$. This led to several studies with the objective of improving the accuracy and precision of the IOL power calculation ${ }^{(4-8)}$.

Classical ultrasound biometry is still used for IOL assortment, but the emergence of new technology using optical biometry has caused a great change in IOL selection. The advantages of the new technology include high precision, noncontact and noninvasive measurements, speed, and superior patient comfort. Among the disadvantages are the high cost of the equipment and the inability to measure dense cataracts, some serious corneal pathologies, lid abnormalities, and eyes with poor fixation.

Recent studies have compared the two methods ${ }^{(8-21)}$. In our study, we found high precision and reproducibility with both methods. The high accuracy level of both technologies was also demonstrated by Packer et al..(14), Kiss et al.(11), and Haigis et al..(15).

The design of our study offered a limitation since axial length measurements were obtained with only one of the two methods used. We suggest and encourage other researchers to do further studies measuring axial length preoperatively with both methods in our population.

In conclusion, we found that $\mathrm{PCI}$ is directly comparable to US with regard to the accuracy and reproducibility of the IOL power calculation. There was a trend toward a subtle improvement in the prediction for postoperative refraction with $\mathrm{PCl}$, especially within close ranges. This finding has also been reported by Bhatt et al. ${ }^{(16)}$

Table 3. Final Outcome

\begin{tabular}{lccr}
\hline $\begin{array}{l}\text { Difference between final spherical } \\
\text { equivalent and preoperative prediction }\end{array}$ & Interferometry & Ultrasound & Total \\
\hline $\mathbf{S 0 . 2 5 ~ D}$ & $34(68 \%)$ & $32(45.7 \%)$ & $66(55.0 \%)$ \\
$\mathbf{0 . 2 5}$ to $\leq \mathbf{0 . 5 0} \mathrm{D}$ & $7(14 \%)$ & $21(30.0 \%)$ & $28(23.3 \%)$ \\
$\mathbf{0 . 5 0}$ to $\leq \mathbf{0 . 7 5} \mathrm{D}$ & $6(12 \%)$ & $7(10.0 \%)$ & $13(10.9 \%)$ \\
$\mathbf{0 . 7 5}$ to $\mathbf{1 . 0 0} \mathrm{D}$ & $3(6 \%)$ & $6(8.6 \%)$ & $9(7.5 \%)$ \\
$>\mathbf{1 . 0 0} \mathrm{D}$ & $0(0 \%)$ & $4(5.7 \%)$ & $4(3.3 \%)$ \\
\hline
\end{tabular}

$\mathrm{D}=$ Diopter

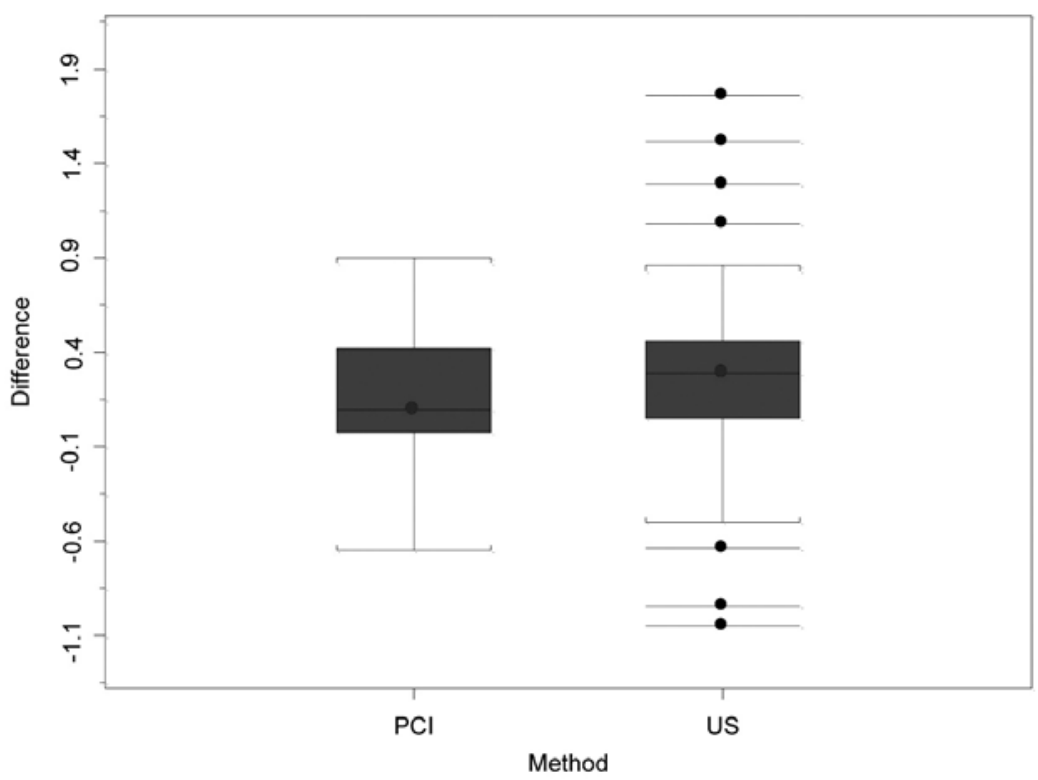

Figure 1.Variability of mean numerical error (difference between achieved and programmed refraction) in diopters between studied groups. 

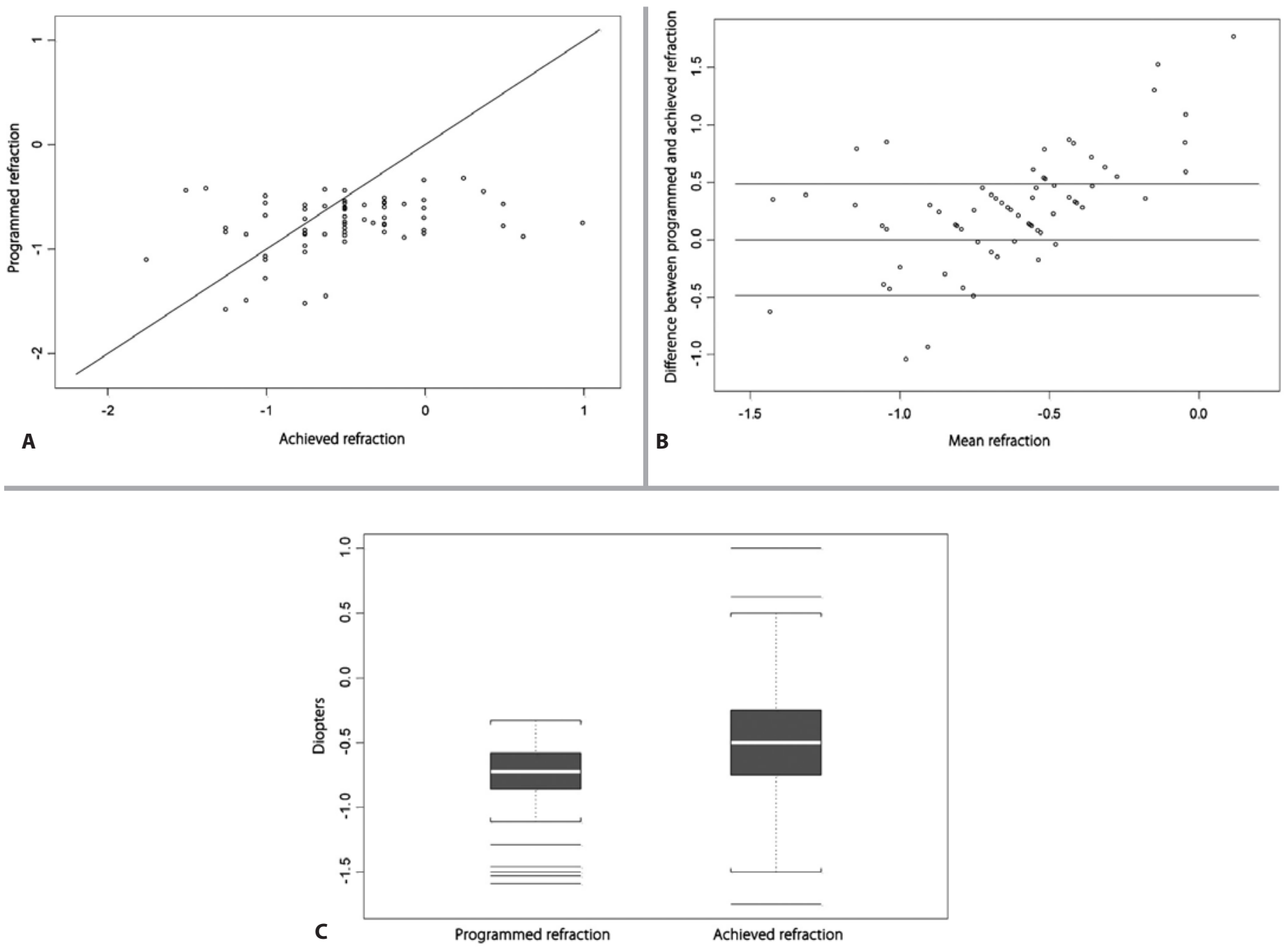

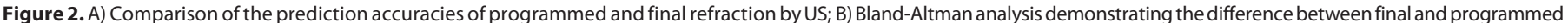
refraction and mean refraction in the US group; C) Hyperopic shift in the US group.
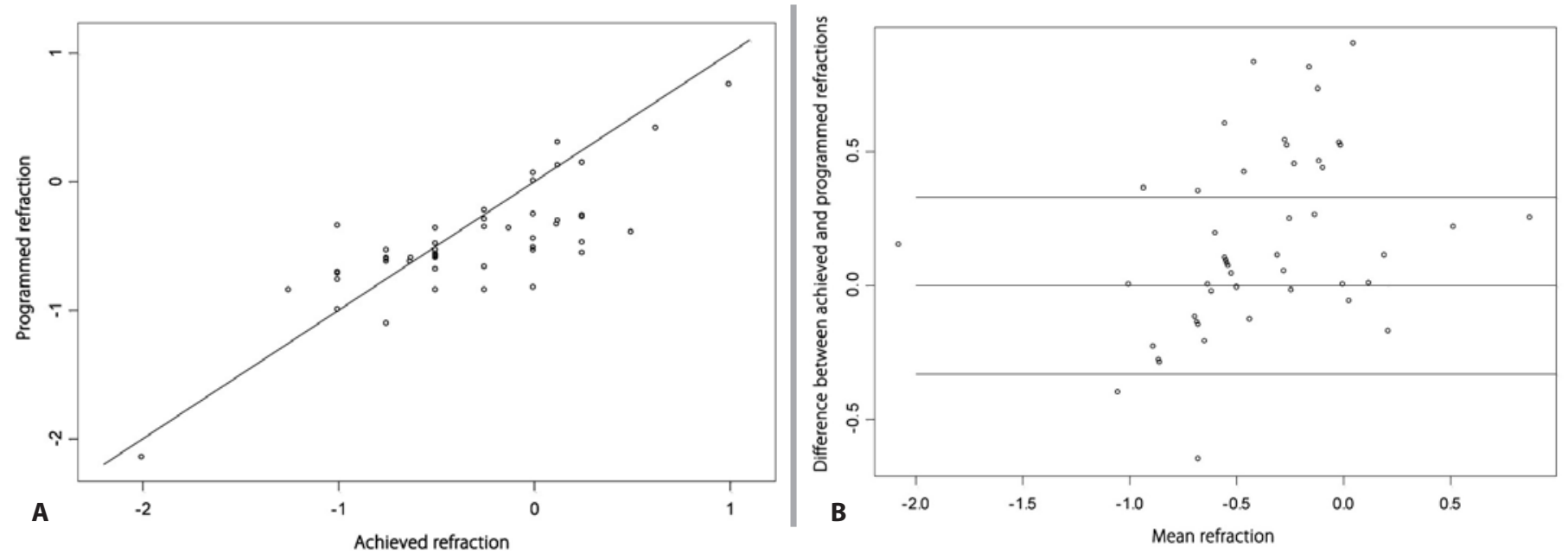

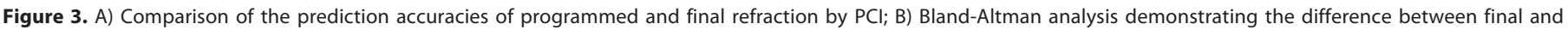
programmed refraction and mean refraction in the $\mathrm{PCl}$ group. 


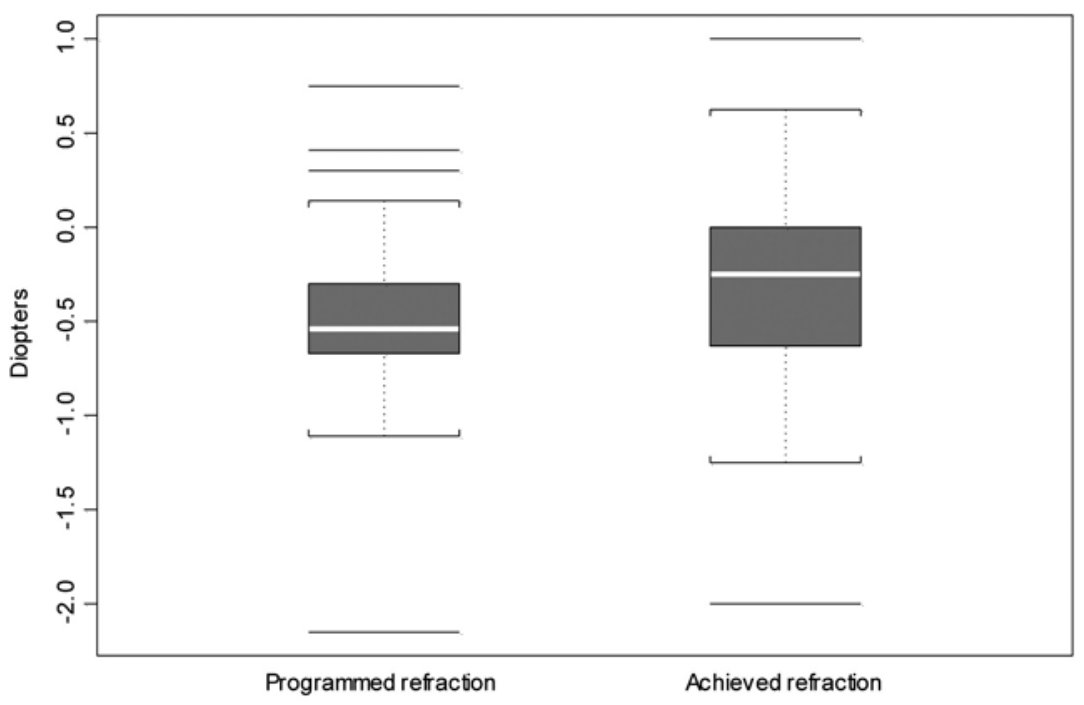

Figure 4. Differences between refractive outcomes in eyes that underwent $\mathrm{PCl}$ and US.

and, more recently, by Landers et al. ${ }^{(22)}$. As surgical methods and materials continue to evolve and as patients' expectations become greater, we should consider the pursuit of excellence with methods that yield superior precision.

\section{REFERENCES}

1. Mamalis N. Intraocular lens power accuracy: how are we doing? J Cataract Refract Surg. 2003;29(1):1-3. Comment on J Cataract Refract Surg. 2003;29(1):85-8.

2. Kora Y, Shimizu K, Yoshida M, Inatomi M, Ozawa T. Intraocular lens power calculation for lens exchange. J Cataract Refract Surg. 2001:27(4):543-8.

3. Jin GJ, Crandall AS, Jones JJ. Intraocular lens exchange due to incorrect lens power. Ophthalmology. 2007;114(3):417-24.

4. Olsen T. Calculation of intraocular lens power: a review. Acta Ophthalmol Scand. 2007; 85(5):472-85.

5. Narváez J, Zimmerman G, Stulting RD, Chang DH. Accuracy of intraocular lens power prediction using the Hoffer Q, Holladay 1, Holladay 2, and SRK/T formulas. J Cataract Refract Surg. 2006;32(12):2050-3.

6. Prager TC, Hardten DR, Fogal BJ. Enhancing intraocular lens outcome precision: an evaluation of axial length determinations, keratometry, and IOL formulas. Ophthalmol Clin North Am. 2006;19(4):435-48.

7. Olsen T, Thorwest M. Calibration of axial length measurements with the Zeiss IOLMaster. J Cataract Refract Surg. 2005:31(7):1345-50.

8. Olsen T. Improved accuracy of intraocular lens power calculation with the Zeiss IOLMaster. Acta Ophthalmol Scand. 2007:85(1):84-7.

9. Rajan MS, Keilhorn I, Bell JA. Partial coherence laser interferometry vs conventional ultrasound biometry in intraocular lens power calculations. Eye (Lond). 2002;16(5):552-6.

10. Kiss B, Find I O, Menapace R, Wirtitsch M, Drexler W, Hitzenberger CK, Fercher AF. Biometry of cataractous eyes using partial coherence interferometry: clinical feasibility study of a commercial prototype I. J Cataract Refract Surg. 2002;28(2):224-9.
11. Kiss B, Find O, Menapace R, Wirtitsch M, Petternel V, DrexlerW, et al. Refractive outcome of cataract surgery using partial coherence interferometry and ultrasound biometry: clinical feasibility study of a commercial prototype II. J Cataract Refract Surg. 2002:28(2): 230-4

12. Connors R $3^{\text {rd }}$, Boseman P $3^{\text {rd }}$, Olson RJ. Accuracy and reproducibility of biometry using partial coherence interferometry. J Cataract Refract Surg. 2002;28(2):235-8.

13. Verhulst $E$, Vrijghem JC. Accuracy of intraocular lens power calculations using the Zeiss IOLMaster. A prospective study. Bull Soc Belge Ophtalmol. 2001;(281):61-5.

14. Packer M, Fine IH, Hoffman RS, Coffman PG, Brown LK. Immersion A-scan compared with partial coherence interferometry: outcomes analysis. J Cataract Refract Surg. 2002 28(2): 239-42

15. Haigis W, Lege B, Miller N, Schneider B. Comparison of immersion ultrasound biometry and partial coherence interferometry for intraocular lens calculation according to Haigis. Graefes Arch Clin Exp Ophthalmol. 2000;238(9):765-73.

16. Bhatt AB, Schefler AC, Feuer WJ, Yoo SH, Murray TG. Comparison of predictions made by the intraocular lens master and ultrasound biometry. Arch Ophthalmol. 2008:126(7):929-33.

17. Remsch H, Kampmeier J, Muche R, Lang GE, Lang GK. [Comparison of the optical coherence method (Zeiss IOL-Master) with two ultrasonographic biometric methods for the calculation of posterior chamber intraocular lenses after phacoemulsification as part of clinical routine]. Klin Monbl Augenheilkd. 2004;221(10):837-42. German.

18. Gantenbein CP, Ruprecht KW. [Comparison between optical and acoustical biometry]. J Fr Ophtalmol. 2004;27(10):1121-7. French.

19. Siahmed K, Muraine M, Brasseur G. [Optic biometry in intraocular lense calculation for cataract surgery. Comparison with usual methods]. J Fr Ophtalmol. 2001;24(9):922-6. French

20. Gantenbein C, Lang HM, Ruprecht KW, Georg T. [First steps with the Zeiss IOLMaster: A comparison between acoustic contact biometry and non-contact optical biometry]. Klin Monbl Augenheilkd. 2003:220(5):309-14. German.

21. Kutschan A, Wiegand W. [Individual postoperative refraction after cataract surgery-a comparison of optical and acoustical biometry]. Klin Monbl Augenheilkd. 2004;221(9):743-8. German.

22. Landers J, Goggin M. Comparison of refractive outcomes using immersion ultrasound biometry and IOLMaster biometry. Clin Experiment Ophthalmol. 2009;37(6):566-9. 